\title{
Correspondence
}

Journal of Medical Genetics, 1982, 19, 158

\section{Inheritance of a ring 14 chromosome}

SIR,

The interesting article entitled 'Inheritance of a ring 14 chromosome' (JMG 1981; 18: 209-13) states that this is the sixth published report of inheritance of ring chromosomes (Burden et al, 1973; Christensen et al, 1970; Palmer et al, 1977; Fryns et al, 1979; Zdansky et al, 1969; Riley et al, 1981). However, it is the seventh, as in 1971 we published a case. ${ }^{1}$

Roland Walbaum

Service de Pédiatrie,

Centre Hospitalier, 59056 Roubaix, France.

\section{Reference}

1 Walbaum R, Maillard E, Dubois B, Mitshiabo E, Pennequin $\mathbf{J}$. Mosaique avec chromosome en anneau surnuméraire chez une enfant malformée, née d'une mère irradiée porteuse elle aussi de chromosomes en anneau. Ann Genet (Paris) 1971 ;14: 63-7.

\section{A new type of osteogenesis imperfecta}

SIR,

In the April 1981 issue of the Journal, ${ }^{1}$ Professor Beighton reported a large South African family in which 20 members in three generations were affected by a syndrome of blue sclerae, dentinogenesis imperfecta, and wormian bones, but without fractures. He suggested that this disorder may be regarded as a new form of osteogenesis imperfecta with autosomal dominant inheritance with consistent expression. Beighton's family are of mixed ethnic origin with Malay, African Negro, European, and Xhoisan ancestry. He speculated that the syndrome may ultimately be identified in diverse ethnic groups in other parts of the world.

We have seen a child who apparently has a fresh mutation of a similar syndrome. She was referred at the age of 4 years for genetic counselling of her parents in March 1979. She was born at term after a normal delivery but was noted to have bilateral clicking hips, effectively treated by splinting. She had been seen by an orthopaedic surgeon, Mr Ruby at Wexham Park Hospital, Slough, in November 1978 for a suspected fracture of her right talus, which was not confirmed radiologically. She was, however, noted to have blue sclerae and a skull $x$-ray showed wormian bones, leading to a diagnosis of osteogenesis imperfecta by Mr Ruby. When we saw her, her mother gave a history that her daughter bruised easily and had loose joints. On examination the child showed blue sclerae, frontal bossing, marked joint laxity, a recent bruise on the back of her left thigh, the opalescent discolouration of the teeth of dentinogenesis imperfecta, and a small open anterior fontanelle. There was no bony deformity and no abnormal scars in her skin. She has normal hearing and vision. A skull $x$-ray showed multiple wormian bones.

None of these features was present in either of her parents, nor in her 8-year-old half-brother born of a previous marriage of her father. The father, born in 1951, has had a single fracture of a leg sustained while playing rugby football. The mother, born in 1954 and unrelated to her husband, suffered a probable Pott's fracture from a fall in which she twisted her right ankle. The mother has two brothers who are blind as a result of Leber's optic atrophy.

Like Professor Beighton's patients this child can be regarded as having a variant of osteogenesis imperfecta. As neither parent and no other member of her family is affected, she presumably has a fresh mutation. Although being similar to Beighton's patients in having the triad of blue sclerae, wormian bones, and dentinogenesis imperfecta without fractures, she is not identical. She lacks the mild femoral bowing and vertebral flattening of his cases but shows frontal bossing, joint laxity, and easy bruising not seen in his family. Hence she represents a possibly further new variant extending the already notable genetic heterogeneity of this disorder. Clarification of the relationship between the different variants will come from biochemical and molecular studies of collagen and its structural and controlling genes.

M d'A Crawfurd and R M Winter Division of Inherited Metabolic Diseases, Clinical Research Centre, Watford Road, Harrow, Middlesex HAI $3 U \mathrm{~J}$

\section{Reference \\ 1 Beighton P. Familial dentinogenesis imperfecta, blue sclerae, and wormian bones without fractures: another type of osteogenesis imperfecta? J Med Genet 1981;18: 124-8.}

